\title{
Marek Kwiek \\ Reforming European Universities: The Welfare State as a Missing Context
}

\section{Introduction}

This chapter is focused on the links between reform agendas and their rationales in higher education and in welfare state services across Europe. Lessons learnt from past and ongoing, as well as recently accelerating welfare state reforms following the fiscal crisis, can be useful in understanding ongoing and future higher education reforms. Research on reforming European welfare states is a missing context in research on reforming European universities. We intend to fill this gap and briefly explore possible links between these two largely isolated policy and research areas.

European universities and European welfare states are closely linked today because they are heavily dependent on public funding - and the competition for public funding between the different claimants to it is on the rise. Reforms of both sectors are also closely linked to increasing intergenerational conflicts over public resources in aging societies, and pressures on both sectors are linked to the shrinking tax base, the power of the neoliberal ideology, and changing social attitudes to both welfare and universities. Problems of both sectors (which are high-spenders in terms of public funding) and solutions to them are increasingly being defined at a global level through transnational reform discourses. The indirect impact of aging societies on all public sector services will lead, it is argued, to growing pressures on all public expenditures and to the increased competition for all public funding. A new context of university reforms in Europe is therefore welfare state reforms. Thinking about university reforms in isolation from ongoing public sector reforms, from the ongoing fierce competition for public funding caused by the aging of European societies, and from future intergenerational conflicts over public resources, is potentially harmful to the university sector. The myth of exceptionalism of higher education among other public sector institutions and of its immunity from global public-sector reform trends increases the chances that higher education will be reformed mostly from the outside rather than mostly from the inside. We believe that it is important for the academic community to understand reforms in the higher education sector - and their rationales - in a wider social, political and economic context, so that the academic community can steer the changes rather than drift with them. Without such wider understanding of changing social realities, the sector may be more vulnerable to externally-driven instrumental reforms. 
Higher education in its traditional European forms has been largely publiclyfunded. Its post-war period of growth in Europe coincided with the development of post-war welfare states across the continent. Massification processes in European higher education were closely linked to the growth and consolidation of European welfare states. Currently, while massification (and universalization) processes in higher education are in full swing across Europe - welfare states are under the most far-reaching restructuring in their post-war history (Bonoli and Natali 2012, Powell and Hendricks 2009, Hemerijck 2013, Palier 2010, Häusermann 2010, as well as Connelly and Hayward 2012). On top of this, European welfare states may be at risk of becoming a "crisis casualty in the cascade of violent economic, social, and political aftershocks, unleashed by the global financial crisis" (Hemerijck 2013: 1). Reforming European universities and reforming European welfare states go hand in hand: the drivers of change are parallel and the overall reform agendas and rationales (financial and ideological) are similar. Universities, increasingly treated as public sector organizations rather than, traditionally, as exceptional academic institutions, are expecting new waves of reforms. On the one hand, "modern society is highly reformistic" (Brunsson 2009: 1), and, consequently, "reforms tend to generate new reforms. Reforms often result from previous reforms, and the outcome of reforms is often new reforms: reforms tend to be self-referential" (Brunsson and Olsen 1993: 42-47). But on the other hand, the notion that changes in higher education can be mandated is "simplistic" (Kezar 2014: xiii). This is clearly the case of most European higher education systems today.

Despite changes in the governance, management and funding of European universities over the last 30 years, policymakers across the continent seem to be systematically focused on further structural changes. European-level developments plus European-level and global debates (such as the Bologna Process, Europe 2020 Strategy, "agenda for the modernization of Europe's higher education systems" or the OECD's AHELO: “Assessment of Higher Education Learning Outcomes" etc.) powerfully support these reformist attitudes (Maassen and Olsen 2007). The emergent picture is clear: "the rate of intended change has accelerated to unprecedented levels" (Enders et al. 2011: 1) and "the signs and portents of change are everywhere" (Schuetze 2012:4, Kwiek 2013a). With a clear reservation, though: "reform is not equivalent to change. An organization may undergo several reforms and emerge with little change. During a certain limited time, some people may merely describe the organization in a new way, with no other consequences for the organization's activities" (Brunsson 2009: 6). While this is not the case for welfare state architectures in most European countries, this might be the case for higher education architectures in some of them. (Poland until recently was a perfect example of higher education reforms not leading to a reformed system or institutions, but not anymore (See Kwiek 2012a, 2012b). 
On reading national governmental strategies and international and transnational reports on the future of higher education, one can conclude that profound transformations of both the higher education sector in general and of the sector of research universities in particular are still ahead of us (EC 2011). The 'modernization agenda' of European universities is strongly linked to wider organizational transformations in public sector services (Maassen and Olsen 2007, Kwiek and Kurkiewicz 2012). 'Transformation' or 'transformational change' is different from three other forms of change (adjustment, isolated change, and far-reaching change), though: "The depth of the change affects those underlying assumptions that tell an institution what is important; what to do, why, and how; and what to produce", as Peter D. Eckel and Adriana Kezar note (2003: 31-33).

The chapter is organized as follows: its section 2 is focused on global agenda-setting and global diffusion of ideas in both welfare state and higher education reforms. Section 3 discusses the impact of aging societies on intergenerational conflicts over public priorities (and public resources). Section 4 links globalization and pressures on welfare states, and section 5 develops a notion of "university attitudes", parallel to "welfare attitudes", as important factors determining the future of European universities. In section 6 the theme of post-industrial societies is analysed, and section 7 raises the issue of the crucial role of supportive discourses in the survival of public institutions. Finally, the role financial and ideological pressures, as well as changing social beliefs in reforming the two sectors is discussed in section 8 , followed by conclusions.

\section{Global agenda-setting and global diffusion of ideas: between transnational and national reform priorities}

The processes of reforming universities across Europe over the last two or three decades did not lead to their 'complete' reforms. They rather lead to further, deeper and more structural reforms. As Enders and colleagues (2011: 1) put it recently, "nowhere today is higher education undergoing more substantial change than in Europe". While detailed arguments in favour of reforms in the two areas studied in this chapter vary over time and across European countries, overall they seem to be increasingly convergent, especially at transnational levels represented by the OECD and the World Bank, as well as, increasingly following the 2008 economic crisis, the European Commission. The former two organizations have been the major providers of analytical frameworks, definitions, large-scale comparative datasets, and extended analyses of pensions, healthcare, and higher education in the last decade, as numerous analysts show in detail. Global interests lead to global agendas along with global diffusion on the one hand, and global data collection and 
analysis on the other hand (Jakobi 2009, Martens, Rusconi and Leuze 2007). The role of "international incentives for national policy-making" increases (Martens and Jakobi 2010). The OECD is a global health actor, a global pensions actor, and a global education actor. It singles out important issues and sets agendas, presents visions and values, develops scenarios, and defines guiding principles and concepts; finally, "it identifies present tendencies and future problems that are later discussed at national level" (Martens and Jakobi 2010: 9). It is able to produce and analyse large quantitative and comparative data sets and indicators. From a global perspective, the state of education, of pensions, and of healthcare is analysed through concepts and definitions used in major OECD publications: the huge Education at a Glance, Pensions at a Glance, Health at a Glance, and dozens of accompanying books. Not surprisingly, in the education sector, education policy statements, including aims and means, "sound increasingly and astonishingly similar all over the world” (Jakobi 2009: 2).

Reforming the welfare state and reforming higher education can be viewed from both research-focused and policy-focused angles. Apart from arguments locating higher education within the welfare state apparatus at a research lev$\mathrm{el}$, at a policy level, with an increasingly globally convergent set of discourses, ideas, concepts, and indicators - referring increasingly to globally-produced comparable data - welfare state reforms are a useful reference point for higher education reforms. Pension, healthcare and higher education (as well as labour market) reforms across the globe are supported by global analyses of "the political economy of reforms", with key determinants of successful structural reforms explained and case studies provided (OECD 2009), plus global studies of "making reforms happen" in such areas as education, health systems, and pensions (OECD 2010). Soft mechanisms involved in "OECD governance" include "idea production", "policy evaluation", and "data production" (Martens and Jakobi 2010: 266-268).

The OECD (as well as the World Bank) has for many years been involved in the process of conceptualization regarding the aging of societies in the context of reforming pension systems (e.g. through its Private Pensions Series, published over a decade). For the academic world dealing with pension systems in international comparative welfare state studies, the ten years of work of the OECD and the World Bank as an academic reference point appears to be relatively insignificant, but in the world of politics (and actual policy implementation) these concepts and works are of key importance. (It is necessary only to see the marginal role of concepts and definitions from both organizations in two recent comprehensive academic accounts of changes to healthcare in the OECD area - Rothgang et al. 2010, Pavolini and Guillén 2013 - and note the marginal role of concepts from leading European political economists involved in international comparative welfare state research 
in the publications of both organizations.) Also, the relationships between research and policymaking in higher education research look quite similar, even though the contribution of the OECD (far beyond the provision of standardized comparative educational statistics) has also been substantial in the last decade. The increasing gap between research and policymaking communities in the sectors studied, however, would require a separate analysis.

Thus apart from a large and increasing body of academic work on welfare states (and especially pensions, by, for instance, Nicholas Barr, Giuliano Bonoli, Peter Taylor-Gooby, Fritz W. Scharpf and Vivien A. Schmidt, Torben Iversen, Jonas Pontusson, Paul Pierson and others), there is also a vast number of conceptualizations for pension reforms emerging from non-academic fields, closely related to policymaking - especially in the work of OECD and World Bank experts. Pension reforms are accelerating across OECD countries; as recent Pensions at a Glance 2013 argues in its editorial:

In OECD countries, the pension landscape has been changing at an astonishing pace over the past few years. After decades of debate and, in some cases, political standstill, many countries have launched significant pension reforms, including higher retirement ages, changes in the way entitlements are calculated and other measures to introduce savings in their pension systems (OECD 2013: 9).

Higher education in Europe has been under powerful reform pressures over the last three decades and prominent higher education researchers viewed the changes as "dramatic", "critical" or "fundamental". Reforms increasingly, and throughout the European continent, tend to produce "further reforms", as shown in various organizational studies (Brunsson 2009: 91, Brunsson and Olsen 1993), though "Many reforms of organizations are attempts to make the existing organization more like a 'true' one, resembling what we think an organization should be" (Brunsson 2009: 41). The modern world likes "true" and "complete" organizations, which are part of its dream of rationality:

We hope to bring about agreement between the way things are and the way things ought to be.... Through various types of reforms, we hope to change our practice in accordance with our wishes and our glowing principles. The modern world is full of such reform projects. Modern society is frantically reformative (Brunsson 2006: 11).

Despite relatively convergent global and European-level arguments in favour of reforms in higher education, there are different directions to current and projected academic restructuring in different national systems and different directions to their implementation (Kwiek 2013a, Kwiek and Maassen 2012, Kwiek and Kurkiewicz 2012). Certainly, the unpredictability and ambiguity of reform attempts is high as reforming universities "is not only about changing social structures, but also about mindsets and values of individuals" - which is not a "straightforward task" (Stensaker et al. 2012: 5). Policy 
implementation literature shows, however, that the role of governments in reforms and change in higher education is of critical importance; as Ase Gornitzka, Maurice Kogan and Alberto Amaral argued, "if it had been left to academics, few of the major structural changes would have occurred" (Gornitzka et al. 2007: 10). What is clear, though, is that higher education is under powerful and accelerating reform pressures and the end of reforms, not to mention their final product, reformed systems and institutions, cannot be envisaged today. For the academic profession, permanent reforms mean high levels of stress and insecurity.

\section{Aging societies and intergenerational conflicts}

We expand the traditional scope of the term 'welfare state' in this chapter, and instead of focusing on what some analysts term its "semantic core" (such as old-age security or healthcare) we discuss one of its "sub-fields": namely, education (Nullmeier and Kaufmann 2010: 89). Consequently, recent paradigmatic changes in viewing welfare state futures are seen here as inevitably linked to possibly equally paradigmatic changes in viewing higher education futures. Historically, the dramatic growth of higher education coincided with the dramatic growth of welfare states in post-war Europe. Now, the restructuring of the foundations of the latter may change the way both policymakers and European societies view the former.

What Stephan Leibfried and colleagues term "the golden-age constellation" of the four components of the modern nation-state (the territorial state, the constitutional state, the democratic welfare state and the interventionist state) is threatened today: "different state functions are threatened to a greater or lesser degree, and subjected to pressures for internationalization of varying intensity" (Hurrelmann, Leibfried, Martens and Mayer 2007: 9). One of the dimensions of the "golden-age constellation" under renegotiation today is higher education policies. Therefore, there is a move back and forth in this chapter between the institution of the university and the institution of the state, especially the welfare state: perceived problems and solutions sought for the latter institution bring about perceived problems and solutions sought for the former institution. They are becoming as inextricably linked as never before.

New ideas leading to changes in the overall functioning of the state and public sector services in Europe can have far-reaching consequences for the functioning of European universities because of, among other things, their fundamental financial dependence on tax-based state subsidization. Both the welfare state and higher education in (Continental) Europe are still heavily dependent on the public purse: what matters is the availability of public funding, the internal competition between the different claimants to public 
funding, and social attitudes to the priorities for public funding. Changing attitudes may lead to changing priorities, and attitudes are linked to such wider processes as intergenerational competition for public resources.

In aging societies, the priorities of older generations (such as healthcare and pensions) may be stronger than ever before, leaving higher education (rather than general education) lower on the list of social priorities (Garfinkel et al. 2010: 193). Resources can be steered "toward pensions and health care and away from educational investments for younger generations. As age conflict increases, the possibilities for age integration decline" (Dumas and Turner 2009: 51). Reforms to both sectors may be parallel but their outcomes may depend on wider social intergenerational conflicts. In the overall context of welfare state expenditures, health care, in comparison with pensions and unemployment benefits, has not shown signs of retrenchment, at least until the recent crisis (Pavolini and Guillén 2013: 276; Rothgang et al. 2010: 247). But it is "in a state of permanent transformation" (Rothgang et al. 2010: 3). In general, attitudes toward the welfare state and other public institutions (including universities), following Stefan Svallfors (2012: 2), can be seen as "central components of social order, governance, and legitimacy of modern societies". Changing attitudes may lead to changing founding ideas of social institutions, and reforms to public institutions may be - although do not have to be $-\mathrm{a}$ reflection of changing attitudes. If changing environments combine with changing attitudes, reforms may be deeper and policy changes - more abrupt. This may be the European case.

\section{Globalization and the welfare state}

Reforms to both sectors have been accelerated by globalization pressures. Globalization powerfully affects both welfare state futures and higher education futures (Kwiek 2006, 2007a, 2007b). The challenges of globalization affecting all public sector services are also accompanied by powerful demographic challenges. As Leibfried and Mau emphasize in their introduction to the three-volume Welfare States: Construction, Deconstruction, Reconstruction (2008: xii), since the oil crises in the mid-1970s

[t] he welfare state has been grappling with deep-rooted challenges. A series of major economic, social and political shifts - such as globalization, demographic pressures, individualization, persistent high unemployment, greater social diversity and fiscal scarcity - have raised the question: How sustainable is the welfare state in the long run?

In general terms, Europe is witnessing a more general attempt at a reformulation of the post-war social contract which gave rise to the welfare state as we know it (with mass or universal public higher education as we know it). 
Europe is facing a simultaneous renegotiation of the post-war social contract concerning the welfare state in Europe (in its major variants) and the accompanying renegotiation of the modern social pact between the university and the nation-state (for a full picture, see Kwiek 2006, 2013a: 107-190). "Nationstates must balance the demands of competing claimants - leaving them with fewer options, but to make hard choices" (Powell and Hendricks 2009: 10). The renegotiation of the (nation) state/university pact is not clear outside of the context of the changing welfare state contract, as state-funded higher education formed one of the bedrocks of the European welfare system in its major forms, and state-funded higher education remains one of its foundations. Welfare state reforms mean what was termed "modernization in hard times":

Modernization refers to the adaptation of existing institutional arrangements to the economic and social structures of post-industrialism: the transition to a (high-skill) service economy, high rates of temporary or long-term unemployment, flexible labour markets, the spread of atypical and female employment, family instability, and mounting demands for individualization and gender equality. The hard times result from the gap between declining resources and the growing (financial) needs that these modernization processes entail (Häusermann 2010: 1).

Education, including higher education, is viewed in this chapter as a significant component of the traditional welfare state. We are thereby following here Joseph E. Stiglitz's Economics of the Public Sector, Nicholas Barr's Economic Theory and the Welfare State; we are also following such social theorists and welfare scholars as Richard Titmuss, Francis G. Castles, Harold L. Wilensky, Peter H. Lindert, Marius R. Busemeyer, Rita Nikolai, and Irwin Garfinkel, as well as Lee Rainwater and Timothy Smeeding (see Titmuss 1968, Castles 1989, Wilensky 2002, Barr 2004, Castells and Himanen 2002, Lindert 2004, Busemeyer and Nikolai 2010, plus Garfinkel et al. 2010). Transformations of the state, and the welfare state in particular, affect - both directly and indirectly - public higher education systems in Europe. The drivers of change in both sectors are parallel, and rationales, especially at a transnational level, are structurally similar, with similar financial and ideological dimensions involved.

All wealthy nations are welfare states (Garfinkel et al. 2010:2) and a hallmark objective of welfare state institutions is to reduce economic insecurity:

Education, health, and some forms of insurance all reduce economic insecurity. [...] social welfare transfers in the form of education, health, and social insurance flow to citizens as a matter of law or entitlement and are paid for by other members of the community by law or requirement.

In knowledge-driven economies, consistent with human capital theories, higher education can be increasingly viewed as a major instrument to reduce 
economic insecurity, at least at an individual level. "Knowledge, and therefore education may be the single most important ingredient in reducing uncertainty and risk. [...] What better way to equip citizens to cope with the economic insecurity produced by a vibrant capitalist economy than to educate them?" (Garfinkel et al. 2010: 23). In knowledge economies, higher education can be increasingly linked to strategies of coping with individual economic insecurity and, consequently, being closer to a traditional pool of welfare services. Ongoing higher education reforms across Europe clearly see this point, stressing graduate employability and the high wage premium from higher education. In very general terms, though, the question of higher education reforms is about "normative" and "operational" modes of higher education being in tune or out of phase across European systems (in Becher and Kogan's (1980) terms, these are the two major dimensions for studying higher education):

As long as the normative and operational modes are in phase with one another, the system as a whole can be said to be in dynamic equilibrium - if not in harmony, then at least in a state of balanced tension. But when the two modes become significantly out of phase, some kind of adjustment is necessary to avoid breakdown and to restore the possibility of normal functioning (Becher and Kogan 1980: 17-18).

Currently, the two modes across Europe are viewed to be out of phase mostly by policymakers, by European societies at large, or sometimes by both; much less often by the academic community. Therefore reform pressures are strong, as "a predisposition for change is created when the normative and operational elements at any level become significantly out of phase. The situation will usually give rise to some appropriate change in belief or practice designed to restore normal functioning" (Becher and Kogan 1980: 120). Reform pressures on welfare state provisions are equally strong, if not stronger (see Kwiek 2013a and 2010 for a wider panorama).

It is hardly possible to view transformations to the institution of the university without viewing transformations to the social fabric in which it has been embedded. The modern university, the product of modernity, is under the very same pressures as other modern institutions and other modern social arrangements. The possible decline of the historical exceptionality of the modern institution of the university (at least compared with the postwar period) results from the same pressures as those affecting other modern institutions - including the institutions of the state, its agencies and public services, international or supranational institutions, and institutions of the private corporate world (see Held and McGrew 2007, Hay et al. 2006, Djelic and Quack 2010, plus Campbell 2004). These pressures are often lumped together as 'globalization' or 'knowledge economy', both closely interrelated. 
As known from organizational studies, reforms need problems and reforms need solutions: a supply of problems needs to be complemented with a supply of solutions, preferably more or less ready solutions (Brunsson and Olsen 1993: 34-42). As Brunsson argues:

Solutions, like problems, can be fabricated by those who wish to pursue reforms; but the task of reformers is easier if a supply of more or less ready solutions is available. Solutions can exert an attraction on those who pursue reforms and on those who are affected by them (Brunsson 2009: 96).

The problems of the two studied sectors are analysed in discourses formulated at a global level, and a set of general solutions to them is also provided at a global level. Transnational reform discourses conceptualize the same problems across the developed world, providing agenda-setting and policy diffusion supported by consistent data generation. These processes, if not directly resulting from globalization, are at least intensified by it.

The question being debated today is not whether recasting the European welfare state has come to be seen as necessary by the national governments of most affluent Western democracies, international organizations, global organizations, and development agencies. The question rather is why it is seen as necessary, and the answers include globalization-related economic integration, demographic changes, changes in societal norms, changes in family patterns etc., and, more recently, the financial crisis. As Maurizio Ferrera explained a decade ago, the fundamental logic guiding policy solutions to the reform processes of the welfare state is that "system-wide searches for novel, economically viable, socially acceptable and politically feasible policy solutions are underway" (Ferrera 2005: 596). Solutions should thus be both fundable and socially and politically acceptable. Transition from industrial to post-industrial societies has

fundamentally challenged social policy arrangements of Western welfare states. [...] In particular, the state is no more able (or willing) to protect citizens against new social risks. [...] The effects of globalization on the development of [the] welfare state are unclear. We do not yet know the specific extent to which globalization will alter socio-political systems and indeed change the course of the entire welfare state models,

as Sipilä et al. (2009: 181) emphasize.

Both higher education services and public sector services are heavily dependent on the social fabric in which they are embedded. They are closely linked to individual countries (nation-states) and their shrinking, or at least increasingly insufficient, tax base. Their modes of governance and funding are always changeable. There is a complex interplay of influences between institutions and their environments, and different schools of thought related to change (Kezar 2014: 24-25, Eckel and Kezar 2003, Bastedo 2012). 
Institutional and neo-institutional theorists present universities as perfect examples of the powerful connectedness between changes in institutions and changes in the outside world (from which they draw their resources, founding ideas, and social legitimacy). The institution of the university in Europe may thus be undergoing a fundamental transformation - along with the traditional institution of the state in general, and the welfare state in particular.

\section{'Welfare attitudes' and 'university attitudes'}

Institutions change over time, and social attitudes to institutions also change over time. What we term here 'university attitudes' in European societies today may be studied in parallel to recently studied 'welfare attitudes'. Stefan Svallfors' large-scale comparative research project on 'welfare attitudes' studied the legitimacy of current welfare state arrangements across European countries and the USA:

Attitudes toward the welfare state and other public institutions should be seen as central components of social order, governance, and legitimacy of modern societies. They tell us something about whether or not existing social arrangements are legitimate. Are they accepted only because people see no alternatives or think that action is futile, or are they normatively grounded? Are institutions considered to be fundamentally just or not? (Svallfors 2012: 2).

In a similar vein, questions about the existing social arrangements in higher education today, leading to ever deeper structural reforms, are about the legitimacy, justice, and normative grounding of these arrangements (or about higher education's institutional "raison d'être"; Olsen 2007).

Reforming higher education systems has been high on the lists of national reform agendas across the continent for 20 to 30 years now, and this has often been associated with theoretical and practical attempts to reform the state, especially with reforming state-provided public services. New ideas leading to changes in the overall functioning of the state and public sector services in Europe can have far-reaching consequences for the functioning of European universities because of, among other things, their fundamental financial dependence on tax-based state subsidization (unlike, for example, in the USA where the dependence on public funding has traditionally been considerably weaker). Ideas matter - what matters in this case is the last two decades of neoliberal thinking about public services and private provision of traditionally public sector services, New Public Management ideas about the public sector, and ideas associated with the state's changing roles under globalization and European integration processes. These ideas seem to have directly and indirectly influenced policymakers' reformist urge to change higher education systems. 


\section{Post-industrial societies and the foundations of the welfare state}

Research literature in political sciences shows that the state is being repositioned, recontextualized, transformed, reconstituted, re-engineered, restructured, displaced, rearticulated, relocated, re-embedded, decentred, reconfigured, reshaped, eroded, etc. We are witnessing its end, hollowing out, withering away, demise, decline, collapse, etc. (Kwiek 2006). Many reservations need to be made but, in very general terms, the economic role of the state is changing, and the 'government versus markets' issue is as pertinent today as it was one or two decades ago. Will the trend be toward continuously growing public spending and higher taxes - or toward less spending and lower taxes? Unfortunately, "no crystal ball exists that can provide us with answers to these questions" (Tanzi 2011: 7). And the direction of the trend in advanced economies matters enormously for the future of welfare states and higher education systems, and reforms to both sectors are destined to follow the trend in spending and taxes. For both high-spenders to be going against the trend seems improbable in the long run, even despite favourable welfare and university attitudes.

The loyalty of citizens to their nation-states has always been related to a bilateral agreement (never fully codified) about the various services nation states provided, including welfare state services. Should the nation-state be threatened, so also will be its role as the primary guarantor of citizenship rights. Redefinitions of what is fair and just in a society within an array of benefits from the welfare state seem to be the easiest way out for policymakers should the welfare state be deemed non-sustainable (the "challenge of sustainability" being at the core of European capitalist welfare societies, as Frericks and Maier (2012) rightly argue). But large-scale restructuring undermines the "personal sense of security and identity as well as social solidarity". Powerful tensions between "social protection" and "global connection" have arisen; as a result of globalization processes "an unprecedented pattern of social risk" (Powell and Hendricks 2009: 8-10) has appeared, as the editors of The Welfare State in Post-Industrial Society: A Global Perspective argue. Renegotiations of the foundations of the welfare state affect the roots of the nation-state - especially the foundations of social citizenship. And the link between the nation-state, welfare state, and nation-state oriented and welfarestate supported higher education institutions has traditionally been very close in the $20^{\text {th }}$ century. Gøsta Esping-Andersen summarized recent changes:

The past few decades have been marked by turbulent change. Turbulent indeed, since the well-trodden corner stones of society, as described in any standard textbook, are eroding as new principles of social life emerge with a thrust that few would have expected. The "logic of industrialism" used to be a forceful 
synthetic concept for what propelled our life as workers, our place within the social hierarchies, and the kind of life course we could expect to follow. As, now, two-thirds of economic activity is centred on servicing, the concept is clearly outmoded (Esping-Andersen 2009: 1).

The post-industrial society shatters the foundations of welfare state assumptions for an industrial society, with new social risks and new social challenges. All four previously mentioned dimensions of the modern state (the territorial state, the constitutional state, the democratic nation state, and the interventionist state) are hugely affected by internationalization and globalization processes (Hurrelmann et al. 2007: 193-205). Globalization processes and increasing international economic integration seem to be changing the role of the nation-state: the nation state is gradually losing its power as a direct economic player and, at the same time, it is losing a significant part of its social legitimacy as it appears not to be willing, or able, to provide the welfare services seen as the foundation of post-war welfare states. Nation-states seem to prefer not to use the financial space of manoeuver still left to them, even if they could be much more pro-active than reactive with respect to the impact of globalization on public services, including higher education. At the same time, "continental welfare states are hard cases for successful welfare state reform: they face both the most urgent need for modernization and the most adverse conditions for that very modernization" (Häusermann 2010: 2).

\section{Institutions and their supportive discourses}

The power of the modern university over the last two hundred years resulted from the power of the accompanying discourse of modernity in which the university held a central, highlighted, specific (and carefully secured) place in European societies (Rothblatt and Wittrock 1993, Wittrock 2003, Kwiek 2006). Any relocation of the institution in the social, cultural, and economic architecture of European nations requires a new discourse to legitimize and justify it as well as sustain public confidence, without which, in the long run, it is hard to maintain a high level of public trust (and, consequently, a high level of public funding).

Therefore, the struggles over future forms of the institution are also, perhaps above all, the struggles over discourses which legitimize its place: in the last decade, those struggles have intensified and for the first time became global, with the strong engagement of international and transnational organizations and institutions.

To a large extent, the future of European universities and of their levels of public subsidy will depend on the social and political acceptance of the new legitimizing discourses currently being produced around them, especially at supranational levels increasingly accepted in policymaking communities 
across Europe, with stronger or lighter "national filters" (see Gornitzka and Maassen 2011). Early formulations of these discourses are already being translated into national contexts, fuelling reform programmes in many countries (post-communist new EU members being prime examples of national translations of OECD reform recommendations, see Kwiek 2012b). Widely accepted supportive discourses for public universities seem to be still in the making, amidst the transformations of their environments (Välimaa and Hoffman 2008).

The whole idea of the welfare state is under renegotiation, and the conditions for access to, as well as eligibility for, various tax-based public services are under discussion (Kwiek 2009a). It is increasingly related to possible individual contributions (co-funding and private policies in healthcare, multipillar schemes in pensions, and cost-sharing in higher education). Government transformations have been following the rules of a zero-sum game over the last two decades: higher expenditures in one sector of public services or public programmes (pensions or higher education) occurred at the expense of expenditures in other sectors of public services (healthcare), public programmes or public infrastructure (roads, railroads, law and order, etc.). What was evident in the period of growth in Europe became even more evident in the recent period of economic crisis: the allocation of budget cuts is different in different countries, with higher education most affected in Hungary, Lithuania, Greece, and the UK (also due to a new funding architecture with increased fees). In more general terms, the aftermath of the global financial crisis may mark a "stress test" for the whole construction of the welfare state in Europe (Hemerijck 2013: 68) and the welfare state might be a "financial crisis casualty" (Hemerijck 2013: 1). The same logic applies to higher education in Europe.

The financial dimension of changes in both welfare state and higher education seems crucial, especially that the total costs generated by welfare state components, as well as each of them separately, cannot easily be reduced. Carlo Salerno formulated the dilemma from the perspective which links resources to changeable social expectations. Salerno discussed an increasingly influential model of the university as a "service enterprise" (one of Johan P. Olsen's four models of university organization, Maassen and Olsen 2007):

Society values what the University produces relative to how those resources could be used elsewhere [...] The 'marketization' [...] does nothing to reduce universities' roles as bastions of free inquiry or their promotion of democratic ideals; it only recasts the problem in terms of the resources available to achieve them (Salerno 2007: 121).

Current reformulations of social objectives of welfare states are occurring at a time when traditional social obligations of the state are under sustained, 
fundamental revisions, and some activities and objectives viewed today as basic could be redefined as remaining outside of traditional governmental duties (Hovey 1999: 60), or as being in need of substantial individual cofunding. The higher education sector is a good example here, as it has to compete permanently with a whole array of other socially attractive forms of public expenditures. In post-communist Europe (much more than in Western European countries), the sector has had to successfully compete with social needs whose public costs have been permanently growing (see Kwiek 2014 on the applicability of typologies of higher education organization and welfare state regimes to Central and Eastern Europe). The ever fiercer battle between claimants will continue and can only intensify in the future.

Viewing the state subsidization of higher education in the context of other competing welfare state claimants to the public purse introduces the 'doing more with less' theme to the higher education reform agenda. State-funded services and programmes have traditionally included healthcare, pensions, and education; but today the costs of healthcare and pensions are expected to escalate in aging Western societies while education, and especially higher education, is increasingly expected to show its 'value for money'.

Higher education may be expected to cut costs, according to the zero-sum logic of competing services and programmes (especially during the fiscal crisis), and to draw on ever more non-core, non-state funding. The increase in the share of non-core, non-state income in European universities has already been substantial, as various comparative data shows (Shattock 2009).

The welfare state after the 'Golden Age' of the 1960s and early 1970s entered an era of austerity that forced it "off the path of ever-increasing social spending and ever-expanding state responsibilities" (Leibfried and Mau 2008: xiii). Similarly, public higher education and research sectors in Europe also stopped being a permanent "growth industry" (Ziman 1994), with ever increasing numbers of institutions and faculty. The transformation paths of welfare states and higher education show close affinities, the difference being in scale and in sequence only. Pensions and healthcare entail huge public spending but higher education is only part of the overall spending on education. The global co-funding agenda for all public sector services seems on the rise today, with fees and loans being implemented or discussed across Europe.

\section{Financial pressures, ideological pressures, and changing social beliefs}

The first type of pressures on public services is financial. The costs of both teaching and research are escalating across Europe, as are the costs of maintaining advanced healthcare systems (Rothgang et al. 2010) and pension systems for aging European populations. As Alex Dumas and Bryan S. Turner 
(2009: 50) argue, "it is well recognized that the welfare states of Europe have rested on an explicit social contract between generations". Any changes in the contract will produce both winners and losers among different welfare state components. Some state responsibilities in some policy areas may have to be scaled down. One of possible areas for social renegotiation is clearly the mass public subsidization of higher education. Even though their outcome is still undetermined, in many European countries the pressure to direct more private funding into higher education through fees and business contracts has been mounting, with the UK as a prime example.

The second type of pressures on public services is ideological. It comes mainly from global financial institutions and international organizations involved in the data collection and analysis of broader public sector services, especially the World Bank (although not its higher education sector, Kwiek 2013a, 2007b). They tend to disseminate the view - in different countries to different degrees - that, in general, the public sector is less efficient than the private sector; its maintenance costs may exceed social benefits brought by it; and, finally, that it deserves less unconditional social trust combined with unconditional public funding. Public perceptions of the public sector in general (just like public 'welfare attitudes' towards welfare services) may gradually influence public perceptions of European universities and the ways they will be funded in the future. New 'university attitudes' - focusing on private benefits and individual goods rather than on the public benefits and collective goods produced in universities - may be gradually formed; they may be more hostile to traditional European full subsidization of public universities and more open to high-fees, high-loans mechanisms prevalent in the USA (Kwiek 2009b).

So alongside dealing with financial pressures and ideological pressures, universities simultaneously have to deal with the effects of changes in the beliefs of European electorates (both 'welfare attitudes' in general and what we term 'university attitudes' in particular), which are of key importance for changes in the positions of leading national political parties.

In these times of the possible reformulation of most generous types of welfare state regimes in Europe (Powell and Hendricks 2009, Palier 2010a, Häusermann 2010), higher education institutions and systems in the next decade should be able to balance the negative financial impact of the possible gradual restructuring of the public sector against the levels of public funding for higher education. And overall trends in welfare state restructuring seem relatively similar worldwide, as Paul Pierson stressed more than a decade ago, long before the recent financial crisis came: "while reform agendas vary quite substantially across regime types, all of them place a priority on cost containment" (Pierson 2001: 456). Or as Castles et al. highlight in their "Introduction" to a recent handbook on the welfare state in a similar vein, 
the two decades of neoliberal intellectual attack "increasingly challenged the optimistic faith in the beneficial effects of big government on which the postwar welfare state consensus had rested". In the context of mature welfare states in the European Union, the deepening of European integration "not only imposed constraints on fiscal and monetary policy, which precluded the practice of traditional Keynesian macroeconomic policies at the national level, it also created 'semi-sovereign' welfare states which became imbedded in an emerging multilevel social policy regime" (Castles et al. 2010: 11). The same effects are felt in new EU member states.

In the case of higher education, the economic outlook of the sector "vis-àvis the intensification of competing social needs, is ever more problematic" (Schuster 2011: 3). The competition for tax funding between various social needs and different public services is bound to grow, regardless of when the current financial crisis will be overcome. The reason is simple, as both studies of welfare and studies of demography show: European welfare state regimes were created mostly for the 'Golden Age' period of the European welfare state model, or a quarter of a century between the 1950s and the oil shock of the early 1970s: "taking a long-term view, we can say that this was a most unusual period" (Lutz and Wilson 2006: 13).

While cost containment may be the general state response to financial austerity across European countries, seeking new external revenues may increasingly be an institutional response to the financial crisis on the part of higher education institutions. This is the core of academic entrepreneurialism: more autonomy through more non-core non-state income (Shattock 2009, Kwiek 2012b). The post-war (Continental) European tradition was tax-based higher education, and (high-level) fees still look non-traditional in most systems. The future of fees has a financial, ideological, and social dimension, and the role of 'university attitudes' shared by particular European nations is as important as spending and tax trends as well as global agenda-setting in higher education and global/national dynamics in policy implementation.

Finally, trends in European demographics (especially the aging of European societies; see the series of OECD books in its Public Pensions Series) will directly affect the functioning of the welfare state (and public sector institutions) in general, with strong country-specific variations. In most European countries, demographics will affect universities only indirectly, through the growing pressures on all public expenditures in general, and growing competition for all public funding. In some countries, such as a number of countries in Central Europe (especially Bulgaria, Romania, Poland, Hungary, and Slovakia, with Poland and its powerfully declining demographics facing projections in the number of students between 2008 and 2025 dwindling by one million according to Kwiek 2012b, Kwiek 2013b, and Antonowicz 2012), the indirect impact on all public services will be combined with the 
direct impact on educational institutions (see also Yamamoto in this section). Strong higher education institutions under such a combination of unfavourable circumstances will be able to steer future changes in funding patterns for higher education in their countries. But steering future changes is becoming an increasingly arduous task, especially since the academic faculty is usually a heavily divided interest group.

The impact of the recent economic crisis on both European welfare states and higher education systems is hard to predict. But as Colin Hay and Daniel Wincott (2012: 224-225) argue in the concluding section of their Political Economy of European Welfare Capitalism,

the most generous welfare states the world has ever known - the Nordic and Continental European welfare states - are here to stay and they are likely to retain their distinctiveness. But they are unlikely to remain as generous as they have been. ... benefit levels and eligibility criteria will be toughened still further.

We do not know its impact on higher education but we can easily imagine that 'welfare attitudes' will not differ substantially from 'university attitudes', and global funding solutions for mass higher education systems will be more popular in Europe than individual national funding solutions, except perhaps for some small and ultra-rich European countries.

\section{Conclusions}

There are several conclusions to be drawn. First, public higher education worldwide is a much less exceptional part of the public sector than it used to be a few decades ago, both in public perceptions and in organizational and institutional terms (governance and funding modes). This disappearing - cultural, social, and economic - exceptionality of the institution of the university will heavily influence its future relationships with the state which, on a global scale, is increasingly involved in reforming all its public services according to transnational agendas, goal-setting, and priorities.

Second, further reforms of higher education systems in Europe seem inevitable, as policy communities promoting changes are global in nature and their recommendations are similar in kind throughout Europe. The forces of change in Europe seem structurally similar, although they seem to act through various "national filters" (Gornitzka and Maassen 2011). National governments still have considerable power in shaping the regulatory frameworks and incentive structures (Enders et al. 2011: 8-9) but national and international policy thinking about higher education is becoming increasingly convergent. Mass (and often universal) higher education is no longer a dominant goal of governments as it has already been achieved; there are many other, competing, social needs. To maintain high public subsidies, universities need to be able to 
produce and defend strong 'supportive discourses' and favourable 'university attitudes'. It has to be clear why mass higher education systems deserve unconditional mass public funding. Nationally-specific answers to this question may matter only to some extent in the context of global agenda-setting and discourse-production. The separation of academic research and transnational expert research (and academic and transnational expert communities) in the two sectors studied is symptomatic of the declining role of the former for the purposes of structural reforms; this is especially clear in the case of higher education research and higher education policy research, which national and European-level policies have seemed largely immune to so far (Maassen and Olsen 2007, Kwiek and Maassen 2012).

Third, it is increasingly difficult to understand the dynamics of possible future transformations of European higher education without understanding the transformations of the wider social world. In particular, transformations to the state in general, and European welfare states in their major variants.

Fourth, the notion of the increasingly competitive nature of public funding made available to different public services is very useful for studying higher education; the allocation of public resources among competing public services is increasingly based on understanding the relative advantages of different public expenditures. Social outputs of spending in one policy area are increasingly assessed, globally and nationally, against social outputs of spending in competing policy areas. Additionally, both 'welfare attitudes' and 'university attitudes' are expected to matter more than ever before in prioritizing social spending.

Finally, it is hard to imagine that the university would not follow the transformations to all other public sector institutions and to the foundations of modern European welfare states. New ideas in the functioning of the state indirectly give life to new ideas in the functioning of 3 universities which in Continental Europe have traditionally been heavily, in both teaching and research, dependent on public funding. The dynamics of current reforms to European welfare states can be mirrored in the dynamics of current reforms to European universities. We suggest here that the better we understand the former, the better we understand the latter; which provides fertile ground for both higher education research and higher education policy research.

\section{Acknowledgement}

The author gratefully acknowledges the support of the National Research Council (NCN) through its MAESTRO grant DEC-2011/02/A/HS6/00183 (2012-2017). 


\section{References}

Antonowicz, D. (2012). "External Influences and Local Responses: Changes in Polish Higher Education 1990-2005”. In: M. Kwiek, P. Maassen (eds.), National Higher Education Reforms in a European Context: Comparative Reflections on Poland and Norway. Frankfurt and New York: Peter Lang. 87-110.

Barr, N. (2004). Economics of the Welfare State. Fourth Edition. Oxford: Oxford University Press.

Barr, N., ed. (2001). Economic Theory and the Welfare State. 3 Volumes. Cheltenham: Edward Elgar.

Bastedo, M. N., ed. (2012). The Organization of Higher Education: Managing Colleges for a New Era. Baltimore: The John Hopkins University Press.

Becher, T., M. Kogan (1992). Process and Structure in Higher Education. Second Edition. London: Routledge.

Bonoli, G., D. Natali (2012). The Politics of the New Welfare State. Oxford: Oxford University Press.

Brunsson, N. (2009). Reform as Routine: Organizational Change and Stability in the Modern World. New York: Oxford University Press.

Brunsson, N. (2006). Mechanisms of Hope: Maintaining the Dream of the Rational Organization. Liber: Universitetsforlaget.

Brunsson, N., J. P. Olsen (1993). The Reforming Organization. Copenhagen: Fagbokforlaget.

Busemeyer, M. R., R. Nikolai (2010). "Education”. In: F. G. Castles, S. Leibfried, J. Lewis, H. Obinger, C. Pierson (eds.), The Oxford Handbook of the Welfare State. New York: Oxford University Press. 494-508.

Campbell, J. L. (2004). Institutional Change and Globalization. Princeton: Princeton University Press.

Castles, F. G., ed. (1989). The Comparative History of Public Policy. Cambridge: Polity Press.

Castles, F. G., S. Leibfried, J. Lewis, H. Obinger, C. Pierson (2010). "Introduction". In: F. G. Castles, S. Leibfried, J. Lewis, H. Obinger, C. Pierson (eds.), The Oxford Handbook of the Welfare State. New York: Oxford University Press. 1-15.

Connelly, J., J. Hayward, eds. (2012). The Withering of the Welfare State: Regression. Basingstoke: Palgrave Macmillan.

Djelic, M.-L., S. Quack, eds. (2010). Transnational Communities: Shaping Global Economic Governance. Cambridge: CUP.

Dumas, A., B. S. Turner (2009). "Aging in Post-Industrial Societies: Intergenerational Conflict and Solidarity". In: J. Powell, J. Hendrick (eds.). 
The Welfare State and Postindustrial Society: A Global Analysis. New York: Springer. 41-56.

EC. European Commission (2011). "Supporting Growth and Jobs - an Agenda for the Modernisation of Europe's Higher Education Systems". Communication from the European Commission. Brussels. COM (2011) 567 final.

Eckel, P. D., A. Kezar (2003). Taking the Reins: Institutional Transformation in Higher Education. Westport: Praeger.

Enders, J., H. F. de Boer, D. F. Westerheiden, eds. (2011). Reform of Higher Education in Europe. Rotterdam: Sense Publishers.

Esping-Andersen, G. (2009). The Incomplete Revolution: Adapting to Women's New Roles. Cambridge: Polity Press.

Ferrera, M. (2005). The Boundaries of Welfare: European Integration and the New Spatial Politics of Social Protection. Oxford: Oxford University Press.

Frericks, P., R. Maier (2012). European Capitalist Welfare Societies. New York: Palgrave.

Garfinkel, I., L. Rainwater, T. Smeeding (2010). Wealth and Welfare States: Is America a Laggard or Leader? Oxford: Oxford University Press.

Gornitzka, Å., M. Kogan, A. Amaral (2007). Reform and Change in Higher Education: Analysing Policy Implementation. Dordrecht: Springer.

Gornitzka, Å., P. Maassen (2011). "University Governance Reforms, Global Scripts and the 'Nordic Model'. Accounting for policy change?" In: J. Schmid, K. Amos, J. Schrader, A. Thiel (eds.), Welten der Bildung? Vergleichende Analysen von Bildungspolitik und Bildungssystemen. Baden Baden: Nomos Verlagsgesellschaft. 149-177.

Hay, C., D. Wincott (2012). The Political Economy of European Welfare States. New York: Palgrave.

Hay, C., M. Lister, D. Marsh, eds. (2006). The State: Theories and Issues. Houndmills: Palgrave Macmillan.

Häusermann, S. (2010). The Politics of Welfare State Reform in Continental Europe: Modernization in Hard Times. Cambridge: Cambridge University Press.

Held, D., A. McGrew, eds. (2007). Globalization Theory: Approaches and Controversies. Cambridge: Polity Press.

Hemerijck, A. (2013). Changing Welfare States. Oxford: Oxford University Press.

Hovey, H. (1999). "State Spending for Higher Education in the Next Decade: The Battle to Sustain Current Support". Report for the National Center for Public Policy and Higher Education. San Jose: Higher Education Policy Institute. 
Hurrelmann, A., S. Leibfried, K. Martens, P. Mayer, eds. (2007). Transforming the Golden-Age Nation State. Basingstoke: Palgrave Macmillan.

Jakobi, A. P. (2009). International Organizations and Lifelong Learning: From Global Agendas to Policy Diffusion. Basingstoke: Palgrave Macmillan.

Kezar, A. (2014). How Colleges Change: Understanding, Leading and Enacting Change. New York: Routledge.

Kezar, A. J. (2012). "Organizational Change in a Global, Postmodern World". In: M. N. Bastedo (ed.), The Organization of Higher Education: Managing Colleges for a New Era. Baltimore: The Johns Hopkins University Press. 181-221.

Kwiek, M. (2006). The University and the State: A Study into Global Transformations. Frankfurt and New York: Peter Lang.

Kwiek, M. (2007a). "The Future of the Welfare State and Democracy: the Effects of Globalization from a European Perspective”. In: E. CzerwinskaSchupp (ed.), Globalisation and Ethical Norms. Frankfurt and New York: Peter Lang. 147-172.

Kwiek, M. (2007b). "The University and the Welfare State in Transition: Changing Public Services in a Wider Context". In: D. Epstein, R. Deem, R. Boden, F. Rizvi, S. Wright (eds.), World Yearbook of Education 2008. New York: Routledge. 32-50.

Kwiek, M. (2009a). "Globalisation: Re-Reading Its Impact on the NationState, the University, and Educational Policies in Europe". In: M. Simons, M. Olssen, M. E. Peters (eds.), Re-Reading Education Policies. A Handbook Studying the Policy Agenda of the 21st Century. Rotterdam: Sense Publishers. 195-215.

Kwiek, M. (2009b). "The Changing Attractiveness of European Higher Education: Current Developments, Future Challenges, and Major Policy Issues”. In: B. Kehm, J. Huisman, B. Stensaker (eds.), The European Higher Education Area: Perspectives on a Moving Target. Rotterdam: Sense Publishers. 107-124.

Kwiek, M. (2010). Transformacje uniwersytetu. Zmiany instytucjonalne $i$ ewolucje polityki edukacyjnej w Europie. Poznań: Wydawnictwo Naukowe UAM.

Kwiek, M. (2012a). "Changing Higher Education Policies: From the Deinstitutionalization to the Reinstitutionalization of the Research Mission in Polish Universities". Science and Public Policy. Vol. 39. 641-654.

Kwiek, M. (2012b). "Universities, Regional Development and Economic Competitiveness: the Polish Case". In: R. Pinheiro, P. Benneworth, G. A. Jones (eds.), Universities and Regional Development: A Critical Assessment of Tensions and Contradictions. New York: Routledge. 69-85. 
Kwiek, M. (2013a). Knowledge Production in European Universities: States, Markets, and Academic Entrepreneurialism. Frankfurt and New York: Peter Lang.

Kwiek, M. (2013b). "From System Expansion to System Contraction: Access to Higher Education in Poland". Comparative Education Review. Vol. 57. No. 3 (Fall). 553-576.

Kwiek, M. (2014). "Changing Higher Education and Welfare States in Postcommunist Central Europe: New Contexts Leading to New Typologies?" Human Affairs. Vol. 24. No. 1. 48-87.

Kwiek, M., A. Kurkiewicz, eds. (2012). The Modernisation of European Universities. Cross-National Academic Perspectives. Frankfurt and New York: Peter Lang.

Kwiek, M., P. Maassen, eds. (2012). National Higher Education Reforms in a European Context: Comparative Reflections on Poland and Norway. Frankfurt and New York: Peter Lang.

Leibfried, S., S. Mau, eds. (2008). Welfare States: Construction, Deconstruction, Reconstruction. 3 Volumes. Cheltenham: Edward Elgar.

Lindert, P. H. (2004). Growing Public: Social Spending and Economic Growth Since the Eighteenth Century. Cambridge: CUP.

Lutz, W., C. Wilson (2006). “Introduction”. In: Wolfgang Lutz, Rudolf Richter, Chris Wilson (eds.), The New Generations of Europeans: Demography and Families in the Enlarged European Union. London: Earthscan. 3-17.

Maassen, P., J. P. Olsen, eds. (2007). University Dynamics and European Integration. Dordrecht: Springer.

Martens, K., A. P. Jakobi, eds. (2010). Mechanisms of OECD Governance: International Incentives for National Policy-Making? Oxford: Oxford University Press.

Martens, K., A. Rusconi, K. Leuze, eds. (2007). New Arenas of Education Governance: The Impact of International Organizations and Markets on Educational Policy Making. Basingstoke: Palgrave Macmillan.

Nullmeier, F., F.-X. Kaufmann (2010). "Post-War Welfare State Development”. In: F. G. Castles, S. Leibfried, J. Lewis, H. Obinger, C. Pierson (eds.), The Oxford Handbook of the Welfare State. New York: Oxford University Press. 81-101.

OECD (2013). Pensions at a Glance: OECD and G20 Indicators. Paris: OECD.

OECD (2010). Making Reform Happen: Lessons From OECD Countries. Paris: OECD.

OECD (2009). The Political Economy of Reform: Lessons From Pensions, Product Markets and Labour Markets in Ten OECD Countries. Paris: OECD. 
Olsen, J. P. (2007). “The Institutional Dynamics of the European University”. In: P. Maassen, J. P. Olsen (eds.), University Dynamics and European Integration. Dordrecht: Springer. 25-54.

Palier, B., ed. (2010). A Long Goodbye to Bismarck? The Politics of Welfare Reform in Continental Europe. Amsterdam: Amsterdam University Press.

Pavolini, E., A. M. Guillén, eds. (2013). Health Care Systems in Europe under Austerity: Institutional Reforms and Performance. New York: Palgrave.

Pierson, P. (2001). "Coping with Permanent Austerity: Welfare State Restructuring in Affluent Democracies". In: P. Pierson (ed.), The New Politics of the Welfare State. Oxford: Oxford University Press. 410-456.

Powell, J., J. Hendricks, eds. (2009). The Welfare State in Post-Industrial Society: A Global Perspective. Dordrecht: Springer.

Rothblatt, S., B. Wittrock, eds. (1993). The European and American University Since 1800: Historical and Sociological Essays. Cambridge: Cambridge University Press.

Rothgang, H., M. Cacace, L. Frisina, S. Grimmeisen, A. Schmid, C. Wendt (2010). The State and Healthcare: Comparing OECD Countries. Basingstoke: Palgrave Macmillan.

Salerno, C. (2007). “A Service Enterprise: The Market Vision”. In: P. Maassen, J. P. Olsen (eds.), University Dynamics and European Integration. Dordrecht: Springer. 119-132.

Schuetze, Hans G. (2012). "University Governance Reform: The Drivers and the Driven". In: H.G. Schuetze, W. Bruneau and G. Grosjean (eds.), University Governance and Reform. Policy, Fads, and Experience in International Perspective. New York: Palgrave. 3-10.

Schuster, J. H. (2011). “The Professoriate's Perilous Path”. In: J. C. Hermanowicz (ed.), The American Academic Profession: Transformations in Contemporary Higher Education. Baltimore: The Johns Hopkins University Press. 21-43.

Sipilä, J., A. Anttonen, T. Kröger (2009). "A Nordic Welfare State in a Postindustrial Society". In: J. Powell, J. Hendricks (eds.), The Welfare State in Post-Industrial Society: A Global Perspective. Dordrecht: Springer. 181-200.

Shattock, M. (2009). Entrepreneurialism in Universities and the Knowledge Economy. Diversification and Organizational Change in European Higher Education. Maidenhead: Open University Press and SRHE.

Stensaker, B., J. Välimaa, C. S. Sarrico, eds. (2012). Managing Reform in Universities: The Dynamics of Culture, Identity and Organizational Change. New York: Palgrave. 
Stiglitz, J. E. (2000). Economics of the Public Sector. Third Edition. New York: W. W. Norton \& Company.

Svallfors, S. (2012). "Welfare States and Welfare Attitudes". In: S. Svallfors (ed.), Contested Welfare States: Welfare Attitudes in Europe and Beyond. Stanford: Stanford University Press. 1-24.

Tanzi, V. (2011). Government versus Market: The Changing Economic Role of the State. Cambridge: Cambridge University Press.

Titmuss, R. M. (1968). Commitment to Welfare. London: George Allen and Unwin.

Välimaa, J., D. Hoffman (2008). "Knowledge Society Discourse and Higher Education”. Higher Education. Vol. 56. 265-285.

Wilensky, H. L. (2002). Rich Democracies: Political Economy, Public Policy, and Performance. Berkeley: University of California Press.

Wittrock, B. (1993). "The Modern University: The Three Transformations". In: S. Rothblatt, B. Wittrock (eds.), The European and American University Since 1800: Historical and Sociological Essays. Cambridge: Cambridge University Press. 303-362.

Ziman, J. (1994). Prometheus Bound: Science in a Dynamic Steady State. Cambridge: Cambridge University Press. 
Higher Education Research and Policy (HERP)

\author{
Edited by Marek Kwiek
}

Vol. 1 Marek Kwiek / Andrzej Kurkiewicz (Eds.): The Modernisation of European Universities. Cross-National Academic Perspectives. 2012.

Vol. 2 Marek Kwiek / Peter Maassen (Eds.): National Higher Education Reforms in a European Context. Comparative Reflections on Poland and Norway. 2012.

Vol. 3 Marek Kwiek: Knowledge Production in European Universities. States, Markets, and Academic Entrepreneurialism. 2013.

Vol. 4 Pavel Zgaga / Ulrich Teichler / John Brennan (eds.): The Globalisation Challenge for European Higher Education. Convergence and Diversity, Centres and Peripheries. 2013.

Vol. 5 Jelena Branković / Maja Kovačević / Peter Maassen / Bjørn Stensaker / Martina Vukasović (eds.): The Re-Institutionalization of Higher Education in the Western Balkans. The Interplay between European Ideas, Domestic Policies, and Institutional Practices. 2014.

Vol. 6 Hamish Coates (ed.): Higher Education Learning Outcomes Assessment. International Perspectives. 2014.

Vol. 7 Gabriella Pusztai: Pathways to Success in Higher Education. Rethinking the Social Capital Theory in the Light of Institutional Diversity. 2015.

Vol. 8 Pavel Zgaga / Ulrich Teichler / Hans G. Schuetze / Andrä Wolter (eds.): Higher Education Reform: Looking Back - Looking Forward. 2015.

www.peterlang.com 


\author{
Pavel Zgaga / Ulrich Teichler / \\ Hans G. Schuetze / Andrä Wolter (eds.)
}

\title{
Higher Education Reform: Looking Back - Looking Forward
}

